Open Access

\title{
Decolonizing vision: Native Americans, film and video activism
}

\author{
Lea Sonza(i)
}

\section{Correspondence: \\ lea.sonza@gmail.com \\ Institut du Monde Anglophone, \\ Université Paris 3-Sorbonne \\ Nouvelle, 5 rue de l'Ecole de \\ Médecine, 75005 Paris, France}

\begin{abstract}
This article provides a critical reflection on, and some key examples of Native American media activism, in particular film and video making. The aim of the article is to discuss the reasons why such activism is important, consider its strength and challenges, as underpinned by the work of critical media scholars, such as Stuart Hall and other prominent scholars. To do so, it provides relevant examples and cases which point at the role of and issues surrounding image, representation, (in) visibility, access, recognition, dissemination, censorship and identity, in relation to video activism.

The main findings are that video activism can be a helpful tool in the frame of Native Americans' struggles for self-making and sovereignty, reversing the trend established historically first by the European settlers, and then by the American 'mainstream' population, whose aim was to erase and assimilate Indigenous peoples. However, although we pinpoint the fact that indigenous media, such as Fourth Cinema or video productions broadcast on platforms like Youtube, are used as political tools by Native Americans, the essay also means to highlight the limits of such tools, whether the latter are theoretical, or practical.

In summary, this article considers traditional indigenous media in self-making processes, mainly through the importance of filmmaking. Furthermore, it emphasizes how resistance, resurgence and sovereignty are pursued with the utilization of digital Indigenous media. It also tries to underline the limits of those methods which should be taken into account to strengthen Indigenous activism. Finally, even if these points are related here to Native American activism, they seem relevant to any kind of activism. It is hence key to highlight that the critical arguments and example provided here can support teachers' work related to social justice. Teachers can use the examples and points made here as a reflection trigger with students in higher education across disciplines and high school, within and beyond the fields that tackle media, culture, sociology, and history.
\end{abstract}

Keywords: Native Americans, Settler colonialism, Visual sovereignty, Fourth cinema, Video activism

\section{Introduction: media power and the perception of Native Americans}

At the opening of the Indigenous Media Symposium which took place in New York City in February 2014, Native American blogger and activist Jarrett Martineau made the following statement: 'everything that [Indigenous people] do is political, everything that we do is already informed by the fact that there is a background of being colonized people, of being dispossessed of our lands, territories, life ways and forms of creativity. So Indigenous Media is always working in some capacity to address the reality

(c) The Author(s). 2018 Open Access This article is distributed under the terms of the Creative Commons Attribution 4.0 International License (http://creativecommons.org/licenses/by/4.0/), which permits unrestricted use, distribution, and reproduction in any medium, provided you give appropriate credit to the original author(s) and the source, provide a link to the Creative Commons license, and indicate if changes were made. 
of the need that we have to decolonize, [and] to represent ourselves in our own terms, not as vanishing but as present, continuing and strong people' (Winton 2014).

This declaration emphasizes the fact that media have always been related primarily to communication, as they can simultaneously be used to make ideas known to a large public as well as to express oneself on a particular topic, while targeting a specific audience with whom there will be a connection. Furthermore, media function through a set of 'delivery mechanisms', that is to say channels through which messages are conveyed. Those channels encompass material as diverse as the printed press, radio, television, cinematic productions and, more recently, the internet (Introduction to Media Theory 2018). They hence can be classified in two categories, 'traditional media' and 'new media'. The former term is generally associated with the printed press, radio, television and cinema. However, the increasing use of the internet and digital technologies gave birth to what can be characterized as 'new media'. Although a thorough definition can be complex to formulate, we will consider in this essay that 'new media' correspond to computer generated and distributed types of media, even though the latter stem from more traditional forms of media (Manovich 2001). Spectacles, representations or intellectual objects which can pass on norms and values, 'new media' provide the ability to disseminate images, sounds and texts to millions of citizens. They also seem to crystalize the basic condition of the 'new information society', characterized by an abundance of information of all kinds (Manovich 2001). Although those new forms of media do not represent a real radical change compared to more traditional forms of media, they stand for a repositioning of our construction of reality (Frau-Meigs 2011), a fact illustrated in the recent boom of social media, defined as the 'websites and applications that enables users to create and share contents, and to participate in social networking' (Rohr-Lopez 2014). Even though social media still present challenges, like the possible repression of the companies controlling them, as well as the State and market control over them, they also offer numerous advantages for action: reduction of costs, time-efficiency, and the promotion of a collective identity, and therefore, the creation of a community (Clark 2012).

Jarrett Martineau's quotation also underlines that, if all the types of media previously cited are crucial in the following discussion, it is because of the link they maintain with the concepts of ideology, hegemony, and power. Along with settler colonialism theory, which cannot be separated from indigenous politics and activism, those will constitute the framework of my analysis. First of all, it is crucial to clarify the concept of 'settler colonialism theory'. The latter can be defined as the 'setting up of a system of power which perpetuates the genocide and the repression of indigenous peoples and cultures, while normalizing settlers' territorial occupation and exploitation of the resources with which indigenous people maintain a genealogical relationship. In other words, 'settler colonialism' implies layered forms of oppression which converge towards the expropriation of indigenous' territories, resources and cultures. This theory is shared by the Native peoples of the United States, Canada, Australia and New-Zealand, and is distinguishable from traditional colonialism because of its main goal of displacement of the indigenous populations, to replace them with populations of settlers' (Cox 2017). The normalization of the settlers' occupation of indigenous territories is hence tightly linked to the idea of hegemony which, according to Italian thinker Antonio Gramsci, contributes to show various notions and events as natural, while they are actually historically and economically constructed, in order to gain the consent of the populations. The idea 
of hegemony can consequently be put in conversation with the construction of ideologies which are used, in a North American context of settle colonialism, to support and maintain the dominant position of the current power (Hall 1995). As a matter of fact, one of media's main sphere of operation is the production and transformation of ideologies. They contribute in making ideas and facts passed as natural when they are actually constructed, answering what the 'hegemonic' instances of power do, in Antonio Gramsci's words, in order to support and sustain their position of domination (Hall 1995).

Indeed, facts are not created equal, but are the 'inherent production of traces and silences'. It is hence key to remember that 'history cannot be the past, it has to be someone's past' (Trouillot 2015). As a consequence, media using visuality, in particular film and You Tube videos, will be analyzed here as both a tool of power and a generator of power, through their capacity to present certain facts, and to disclose others. Their use can allow the power in place to reproduce itself. In the words of American anthropologist Eric Wolf, quoted in an article of American researcher Daniel Cobb, 'power is involved in deciding who can talk, in what order, through which discursive procedures and about what topics', and is hence able to exploit the media in order to build ideologies on which it can be constructed and accepted (Cobb 2002, 42). As Stuart Hall examined it, media do not only present images, but they are engaged in representing images that have several meanings. Those meanings then have an influence on public history and memory of historical events, as they prescribe our understanding of the present and of the past, including false narratives within our system of beliefs (Murphee 2016). An important part of Native Americans themselves grew up impacted by the way mainstream media depict 'Indians', and needed to excuse themselves for not answering the codes given by the mainstream (Conversation with Elizabeth Ellis 2018).

However, media can also be used to disturb, to a certain extent, the dominant system of power, challenging the ideologies in place with the production of new meanings, images and narratives (Hall 1995). This work focuses specifically on the utilization of traditional and new media by various individuals and communities belonging to Native American Nations in the United States. It will aim at presenting an analysis of those media in relation to indigenous politics, bringing at the foreground the emergence and use of 'indigenous media', described as 'forms of media expression conceptualized, produced, and circulated by indigenous peoples, as vehicles for communication and self-representation, for cultural preservation and artistic expression, and for sovereignty and political self-determination' (Wilson 2017).

Indeed, the position of Native Americans in the national, white American psyche is ambiguous, grounded in two interlocked traditions of self-criticism and conquest (Deloria 1998). 'Non-Indians' seem to narrate their own present against what they constructed as a backdrop of the past, symbolized by Native American people and their culture (O'Brien 2010). The previous notion is closely related to how the idea of race was conceptualized in a North American context, placing some people in a natural situation of inferiority compared to others, to legitimate the relation of conquest and domination which was constructed throughout more than four centuries. Drawing on a Hegelian conception of history as linear, settlers from European origin considered themselves as superior and representing 'modernity'. Even though they needed indigenous people from the beginning to survive and then settle down on the continent, colonizers built a hierarchy where indigenous were inferior and denied political and cultural sovereignty (Quijano 2000). In spite of the traumatizing events which ensued 
from the implementation of that ideology, and its translation into concrete policies like removal or erasure, American Indians have been practicing resilience to large-scale and long-term adversity (Reinschmidt 2016), and in 2015, more than 500 Nations were still officially recognized by the United States government, while almost seven million people were self-identifying as being American Indian or Alaska Natives, mixed or not (www.census.gov).

Despite that growing number, the twofold of ideology and concrete policies reflecting the interests of settlers which has been constructed throughout the centuries still causes, nowadays, a major problem of visibility, or more precisely, of invisibility. If we go back on the historical specificity between vision, racial differences and the media, it is possible to say that media is a vital terrain on which to look for visibility, although this visibility has to be chosen, through techniques of self-making allowing resistance and resurgence in visual spaces. Consequently, in the sixties, while American Indian leaders, scholars and communities embraced the social and political goal of self-determination, cultural renewal and revitalization, Natives also entered the media world as actors, and no more as objects of the mainstream media (Walker 2011). By 'mainstream' the article considers western forms of representation (Davila 2018a, b, c) which triggered, as a quotation from mass media historian Jane Rhodes explains it in Vanessa Murphee's Routledge Companion to Media and Race, 'the struggle between the transmission of racial ideology and the efforts of opposition groups to claim control over their image' (Murphee 2016, 23).

In the past decades, indigenous people increasingly appropriated the technology of the dominant, 'mainstream, settler society and transformed it to fit their own use, to meet their own political and cultural needs, 'shooting back at the colonial master' (Wilson and Stuart 2008) with the goal of decolonizing vision as a premise for fighting for self-representation and sovereignty. Indeed, in representing themselves in the media, Native Americans have demonstrated 'an act of creative authority', emphasizing the basic issue of self-representation and self-determination (McLaurin 2014).

Knowing that, we can wonder to what extent Native Americans use both traditional and new media in a contemporary context, as scholars, artists or activists, to foster sovereignty, self-representation and cultural preservation, re-appropriating what was traditionally a colonial tool of domination and using it for self-making purposes.

To answer the problem statement, this article first considers traditional indigenous media in self-making processes, mainly through the importance of filmmaking. Then, it will emphasize how resistance, resurgence and sovereignty are also pursued with the utilization of digital indigenous media, and the increasing use of 'Web 2.0'. Finally, it will try to underline the limits of those methods which should be taken into account. In summary, this article provides a critical reflection on, and some key examples of Native American media activism, in particular film and video making. The aim of the article is to discuss the reasons why such activism is important, consider its strength and challenges, as underpinned by the work of critical media scholars, such as Stuart Hall and other prominent scholars. Furthermore, it provides relevant examples and cases which point at the role of and issues surrounding image, representation, (in)visibility, access, recognition, dissemination, censorship and identity, in relation to video activism. These points are related to Native American activism here but are relevant to any kind of activism. The critical arguments and example provided here can support teachers' work related to social justice. Teachers can use the examples and points made 
here as a reflection trigger with students in higher education across disciplines and high school, within and beyond the fields that tackle media, culture, sociology, and history.

\section{Methodology used in the research}

The aim of the study is to provide a critical discussion of the history, challenges, possibilities and nature of Native American film and new media activism. The latter media being traditionally considered as 'Western', the purpose is hence to underline how Native Americans succeeded in re-appropriating them in a contemporary context, and what it implies for their own cultures and struggles, as well as for the modification of the mindsets and structures of power in the 'mainstream' United States.

In the frame of the analysis, the methodology consists in confronting indigenous critical theory and practice, by examining simultaneously the works of Native American scholars on what should be done to decolonize vision, culture and politics, and how artists and activists actually carry it out. In order to do so, opinions of people as diverse as filmmakers, scholars or social workers are presented throughout the following article, stemming from interviews or conferences. Despite those testimonies, it is crucial to insist on the fact that indigenous cultures are so numerous and diverse, that there is an absolute need not to generalize statements, even though there are many points of convergence within the different discourses.

The following study is hence nourished by various critical indigenous theories. The latter are framed by the concept of settler colonialism, as underlined in the introduction, and incorporate an indigenous definition of what visual sovereignty means, why it matters, and how it could lead to a concrete political sovereignty which seems necessary to pursue indigenous resistance and foster resurgence, while fighting Western ideologies built to satisfy settlers' economic and territorial interests. These theories also consider how Native Americans link the former idea of visual sovereignty with the emergence and development of indigenous media, considered as vectors facilitating the reappropriation of indigenous images and narratives.

Consequently, the research is also supported by the scrutiny of several recent cinematic productions and Youtube videos, chosen in relation with the topics of the re-making of Native American history to foster critical thinking, or the importance of video activism to deconstruct stereotypes and encourage indigenous resistance and resurgence. The films used in this project were chosen for different reason. If Smoke Signals (https://123movieshub.fm/film/9123-smoke-signals.html\#) and The Exiles (https://aifg.arizona.edu/film/exiles-part-1, https://aifg.arizona.edu/film/exiles-part-2) are mentioned, it is to show an example of productions which made their way to a wide audience, while being almost entirely directed, acted, and produced by Native Americans. They hence had the capacity to question the former messages that Western productions usually conveyed about 'Indians'. As for The Reawakening (https://efetish movies.ga/pub/full-downloads-movies-the-reawakening-by-diane-fraher 640x640.html), a fiction which is less known to the large public, and Sikumi (http://www.ontheicethe movie.com/) and Kinnaq Nigaqtuqtuaq (http://filmcatalog.nmai.si.edu/title/2452/), which are documentaries and hence reach a specific type of viewers, they are representative of the values that the two indigenous film directors I could interview in New York City wanted to pass on in their cinematographic creations. What is more, the selected Youtube videos (https://www.youtube.com/watch?v=NuzPoidV4nI, 
https://www.youtube.com/watch?v=BmFxJYFSXy0) were chosen because they showed, through the sketches of an increasingly famous group of indigenous comedians, that humor was a powerful tool to decolonize Native Americans' image. Indeed, the comedians succeed in bringing together an efficient and traditional tool of resistance with the capacity of new technology, the latter strengthening the former. To finish, it is important to remember that the video material was produced by members of different indigenous nations, displaying the common thread, but also the differences, in contemporary Native struggles.

\section{Traditional indigenous media: filmmaking as the road to self-making that challenges stereotypes and ideologies built by mainstream media}

The main settler colonial ideology that indigenous people have to challenge through self-making in the media seems to be the myth of Manifest Destiny (Risling Baldy 2016). Manifest Destiny can be defined as 'the belief held by most whites that they were entitled to the land by virtue of their innate superiority and religious mission, while promises and treaties made to and with Native Americans between 1778 and 1871 were not considered of importance' (Lee and Summerfield 2006). This concept, which shaped the making of the North American settler society, was expressed through movie productions like the Western genre for example, which was born in the late twenties and early thirties and showed a Hollywood vision of Native Americans as blood thirsty, intellectually limited, and easily conquerable as they were ahistorical and predestined to disappear. Two other serious issues were related to the acting performance in mainstream movies: many Native American actors were forced to enact 'redface' performances for Indian roles, as 'Indianness' was interpreted through the colonial gaze. But a lot of non-Natives were also doing so, as they were often casted to play Native Americans (Raheja 2010). One of the major issues is that those tropes perpetuated by mainstream media had, and still have, an important influence on society (Herrington 2011). As American sociologist Todd Gitlin would say in Jason Heppler's article 'Framing Red Power', 'media are particularly powerful in shaping people's view of the world, through selection and omission, emphasis and themes. Mass media are a significant social force in the forming and delimitating of public assumptions, attitudes and moods' (Heppler 2009, 25).

If mass media rhyme with obliteration, as a consequence, indigenous media are supposed to create locality and cultural authenticity (Davila 2018a, b, c). Decolonizing media goes along with the idea that indigenous people of the United States can respond through their own productions to the misrepresentation of their people and start the revision of the Indian portraying made by Hollywood (Heppler 2009). Over time, they have been depicted as exotic and vanishing, as innocent or dangerous, and as colonized by 'more advanced civilizations', while their distinct cultures were shown as monolithic and stereotypical, posing a problem of self-identification (Marrubio and Buffalohead 2013). Revisionism and representation accuracy then become the major challenges, as well as the need to invert the common plotlines and narrative structures to give Native Americans nuances and agency (Boyd 2015). Through getting control over their own representation, their goal is not only to question the old stereotypes quoted previously by getting people used to break down images and narratives, but also to give new, positive and contemporary narratives of Native people to replace the old ones (Panel 
Discussion, 'Indigenous New Media Symposium' 2014). Gaining visual sovereignty through self-making in the media is a way of reimagining native-centered articulations of self-representation and autonomy, that engage the powerful ideologies of mass media but do not rely solely on the texts and contexts of the Western system (Raheja 2010). In doing so, three important concepts have to be considered: offering power to the powerless, raise political awareness among Natives themselves, and gaining visibility (Heppler 2009).

Indeed, in addition to reaching out to indigenous people, the fact of living in a system created by, and for, non-Natives, also pushes Natives to raise awareness among the white audience, to facilitate the back up of their claims but also to make more resources available to fulfill diverse kinds of projects (Panel Discussion, 'Indigenous New Media Symposium' 2014). In other words, one other aim of indigenous people who are working in the media field is to 'get the right people interested by the right things' (Deloria 2004, 75).

\section{Expressing resistance and resurgence to build the path towards sovereignty}

If indigenous media's purpose is to challenge Western ideologies built on stereotypes of Native people, they simultaneously convey a message emphasizing indigenous resistance to the mainstream culture, while underlining a resurgence of the Native ones. Indeed, the notions of resistance and resurgence seem primarily linked to the practice of cultural traditions, in their original and contemporary form, as the latter have a decolonizing power and allow Indigenous people to 'escape the cage of Empire' (Simpson 2016). As Stuart Hall puts it, culture is a site of struggle because discourses produced by institutions such as governments or social groups are contested (Littlejohn and Foss 2009).

Then, it is also key to point out that resistance and resurgence through culture are also tied to the complex notion of sovereignty, and to the specific interpretation indigenous people have of the concept, which competes with the American understanding of it as shaped by spatial and temporal boundaries produced by a definite paradigm of binary narratives and images. The American interpretation hence emphasizes 'the efforts of the citizens, institutions and government of the United States to restrain indigenous people seeking to maintain and secure their cultural, economic and political practices over time'. Using the loopholes of the Western application of the idea, Native Americans claim sovereignty as being 'the ability of a group of people to make their own decisions and control their own lives in relation to the space where they reside or that they envision as their own', to shape a modern status on their own term. Therefore, as a category of scholarship, activism, governance, and cultural work, sovereignty matters in consequential ways to understanding the political agendas, strategies, and cultural perspectives of indigenous peoples in the Americas. Following World War II, sovereignty emerged as a particularly valued term within indigenous scholarship and social movements as well as through cultural production. It was a term through which indigenous intellectuals and artists represented their histories, cultures, and identities, often in opposition to the erasures of their sovereignty by dominant ideologies of race, culture, and nationalism coined in the discourses of American patriotism and settler colonialism (Bruyneel 2004, 12).

Native American resistance using traditional media started mainly with the printed press and political claims. Indigenous people tried at first to confront the problem of being only presented and represented by a white-controlled press, by creating their 
own newspaper, like the Cherokee Phoenix as early as 1828. It was supposed to present a different point of view on Indian affairs. Besides, tribal newspapers contributed in reflecting the Native readers' rising sense of tribal identity and nationhood (Loew and Mella 2005). Both the indigenous and mainstream printed press were above all used in the late sixties and early seventies, when organized social and political movements like the American Indian Movement (AIM), attempted to communicate their agenda through mass media. Born in the prisons of Minneapolis, AIM developed mainly in urban settings, and symbolized a renewed indigenous identity, as well as the rise of the 'pow-wow' culture embodying a new Native generation. Although the demands of the members were broad and sometimes unclear, their activism started to claim space for 'Indians' (Ellis 2018a, b). Their politics, at the time, was framed by the work of Vine Deloria Jr., which provided the movement with defined problems, offered solutions, and identified the agents of change. Using the printed press was a way to connect with a certain type of audience and to raise awareness among both Natives and non-Natives (Heppler 2009).

Over time, Native people diversified their use of the media, and in 1976, the Native American Public Telecommunications (NAPT) became the first minority consortia organization to receive a corporation for public broadcasting grant. In the decades following its creation, the NAPT has served as a springboard for Native media productions, whether presented under the form of documentaries and fiction films or based within the 'promising realm of new media, foreshadowing the fecund creative and political work of self-making pursued by American Indian individuals and communities (Adams 2017).

\section{The birth of the fourth cinema: looking for an alternative}

While interviewed, Osage film director Diane Fraher stated that 'the core of Indigeneity [was] resistance,' associating her art with both resurgence and resistance through storytelling, and pointing out the powerful impact of the visual translated in filmmaking (Fraher 2017).

As exposed previously, mainstream media appear as a vehicle for the settler colonial ideologies, which were partly built on misrepresenting Native Americans to justify settlers' policies while trying to invalidate Natives' claims of sovereignty and self-determination. In investigating how Native American, through the use of indigenous media, have been working to access a self-representation which would grant them control over their own images and narratives, it is critical to start the analysis by studying the re-appropriation of traditional media by the same people who were for so long the 'victims' of institutions like Hollywood, through an examination of what is known as the 'fourth cinema'.

'Fourth cinema' is a form of filmmaking which 'put the emphasis on self-representation to replace the tropes of the mainstream cinema, negotiating with it while negotiating Indigenous identity itself'. In the reported words of New Zealand filmmaker Barry Barclay, it is supposed to 'move away from the indebtedness to national film, to reclaim its history and land, to create its own conventions and techniques of filmmaking, and finally its autonomous identity' (Herrington 2011, 6). Fourth cinema was hence born when indigenous filmmakers started to talk back to Hollywood. A quote from artist and scholar Jolene Rickard backs up this definition by saying that gaining sovereignty in visual art was the border that 'shifted indigenous experience from a victimized stance to a strategic one' (Hearne 2012, 15). 'Films become a way to go back, to look at one's self and to identify 
the old ways that have weight, depth and truth, in order to counter the contamination in Native people's lives today'(Marrubio and Buffalohead 2013, 253). By becoming producers, directors and filmmakers of their own stories, Native Americans have a possibility to regain control of their images and to be able to combat both stereotypes and the exclusion of their people in the creative process. Indigenous filmmakers are key to change the narratives and the visual aesthetics of the films (Boyd 2015).

Fourth cinema as adapted by Native Americans living in the United States is deeply connected to the current struggles the different communities are facing. As a citation of Professor Chadwick Allen specifies, 'the origins of Native American cinema are made to evoke the blood, land and memory complex, and are supposed to assert indigenous distinctiveness through linguistic, stylistic and content markers of indigenous identity' (Mayo 2013, 8). In practice, the latter statement means a difference of form and content in the way indigenous people make their movies. For example, Native American cinema follows three modes of representation: the familial space of Native Americans' homes, the vision of American Indian protagonists and the figuration of historical trauma through indigenous temporal structures (Mayo 2013). Furthermore, even if indigenous films exhibit so much diversity that it is impossible to generalize about them, some common features can be found. It tries to rely on indigenous personnel in the production process, and on Indigenous filmmakers' specific ways of working, while securing Indigenous contents. Besides, there are usually more documentaries than feature films released, as they are cheaper, easier to fund, and present specific stories grounded (Marrubio and Buffalohead 2013). Bird Runningwater, who works at the Sundance Institute, pointed out that 'the root of Native American filmmaking lied in documentary', as it is necessary to challenge the dominant myths with a portrayal of nuanced and lively human beings (Adams 2017). To finish, the screening often presents indigenous storytelling forms, which translates a culture's specific oral tales, focuses more on groups than on individuals, and uses time as multidimensional rather than linear (Marrubio and Buffalohead 2013).

Sherman Alexie’s Smoke Signals (https://123movieshub.fm/film/9123-smoke-signals.html\#) was a watershed in relation to the previous definition, as it was, in 1998, the first movie circulated inside the mainstream distribution system which was entirely directed and acted by Native Americans. However, movies like Kent Mackenzie's The Exiles (https://aifg.arizona .edu/film/exiles-part-1, https://aifg.arizona.edu/film/exiles-part-2), which depicts a urban periphery next to Los Angeles and looks at the protagonists' personal engagement with their space also illustrates the birth of fourth cinema (Mayo 2013).

Diane Fraher, an Osage woman who is now living in New York City and directed movies like The Reawakening (https://efetishmovies.ga/pub/full-downloads-mov ies-the-reawakening-by-diane-fraher-640x640.html), which relates the experience of a man of American Indian origin living in an urban setting and having to go back to his relatives' reservation, said that she chose to become a filmmaker because she 'liked telling stories too much'. Besides, she stated 'that [she] did not want to abide by non-Natives' expectations of what a Native person should be, or worse, not even thinking about [her]self as Native because of the assimilation process (Fraher 2017). Andrew Okpeaha MacLean, born and raised in Alaska among the Inupiaq Nation, and now professor of filmmaking at New York University as well as film director, translates in his movies 'his experiences as an individual, as a member of the Inupiaq Nation and as an 
Indigenous person at large'. He uses his love for storytelling and his awareness of the artistic responsibilities linked to filmmaking to make people know that Inuit are alive and to present them realistically, to fight the branded images of 'eskimos', usually associated with commercial products like ice-creams (MacLean 2018).

Author of several short movies, each of them seems to present for a different message. Sikumi (On the Ice)(http://www.ontheicethemovie.com/), which premiered at the 2008 Sundance Film Festival and shows in the original Inupiaq language a murder on the ice floe, deals with a large scope of thematic like friendship, kinship, responsibilities, alcoholism and materialism. Kinnaq Nigaqtuqtuaq (The Snaring Madman) (http:// filmcatalog.nmai.si.edu/title/2452/), takes place, on the contrary, within an urban setting. Adapted from a traditional Inupiaq story, it blurs the line between fantasy and reality, as a metaphor for the difficulties that Indigenous people are likely to face while disconnected from their lands and communities (Maclean 2018).

\section{Digital indigenous new media: a tool of resistance and resurgence?}

With the proliferation of representations made possible by new media technology and distribution platforms, will the interests, variety, and reach of representations of race and ethnicity challenge and destabilize the structure and cultural dispositions of identity, self, community, belonging and politics to which we had become so accustomed?

The question becomes relevant while comparing the expectations that communities have concerning computer-based media and the reality of the latter. Digital realms are considered as more open than traditional cinema to those who are marginalized within dominant image systems (Hearne 2017). The internet in particular, provides First Nation people with a medium through which they can accurately represent issues of place, time and performance, especially because of digital media are more accessible, their distribution being less problematic than the one of traditional media (Keene 2016). Therefore, computer-based technologies are seen as a place allowing decolonization through accurate representation. What is more, Native people embrace and exploit new communicative technologies also to legislate for sovereignty and the control of their identities, histories and representations (Fish 2011).

The Indigenous New Media Symposium seems to illustrate the latter statement. Held in February 2014 in New York City, the Symposium brought together prominent Native American media makers and creative activists to discuss how new media were being used in Indigenous communities to educate, organize, entertain and advocate. The underlying message was that new media changed the way indigenous people relate to each other and convey information. As a matter of fact, new media do help structuring counter-narratives to critique the myths built by mainstream media, while deconstructing the state of imbalance some Native American are living in without even knowing it (Panel Discussion, 'Indigenous New Media Symposium' 2014).

Among the participants, Cherokee scholar, professor and activist Adrienne Keene talked about her own experience as a Native person moving East of the United States and being the only indigenous person of her promotion. She highlighted how media were useful in creating a consciousness about the mere existence of Native people, when sometimes settlers' descendants are not even aware that they still exist (Panel Discussion, 'Indigenous New Media Symposium' 2014). She also pinpointed that one of the important tools of self-making on the internet were Blogs, that is to say organized 
online publications hosted by a platform accessible to all kind of authors and public, allowing the former to express themselves on chosen topics at a personal level, and the latter to react to the publications. Her own Blog, Native Appropriations (http://nativeappropriations.com/), deals with what is problematic about cultural appropriation (Risling Baldy 2016). The power of blogs lies in the fact that they give time to think properly and then to write about a question. They are also a way to translate academic concepts and vocabulary, which can be challenging and hence keep some people out of the debate, to a wider audience (Panel Discussion, 'Indigenous New Media Symposium' 2014). In the same vein, Turtle Mountain Chippewa Jessica R. Metcalf, created a fashion blog entitled Beyond Buckskins (http://www.beyondbuckskin.com/), to fight against the fashion world's appropriation of Native culture and outfits and to promote a responsible consumer behavior by selling products designed and created by Native artists. It also fosters self-representation by showcasing and promoting those artists, and advance creative small businesses located throughout rural and urban communities (Panel Discussion, 'Indigenous New Media Symposium' 2014).

The speakers also insisted on the importance to raise awareness among non-Indigenous people to allow them to have conversations with indigenous people afterwards (Panel Discussion, 'Indigenous New Media Symposium' 2014). In relation with this, new media are changing the conversation for Indian Country, as the digital age brought an increased attention on Native specific issues from outsiders, an observation which is especially accurate within the social media field, as we will see in a second subpart (Walker 2014). However, even if it is important to engage with the mainstream on-line community, it is equally crucial to keep in mind that 'popular culture can be a vehicle for social change but has worked for Native people as well as against them' (Risling Baldy 2016, 101).

\section{Playing with visuality on Youtube}

Still focusing on the role of indigenous new media to 'educate, organize, entertain and advocate' (Panel Discussion, 'Indigenous New Media Symposium' 2014), the following part puts the emphasis on the use of humor on the internet, through video sharing websites in general, and Youtube in particular. Created in 2005, the latter platform allows individuals to interact with the global community by viewing and sharing user generated video content. Having around seventy-eight million users nowadays, it can be used as a device to make traditional stereotypes about certain groups of people decline, becoming a form of 'video activism' (Sawyer 2011).

Furthermore, mentioning the words of Laguna Pueblo poet, activist and scholar Paula Gunn Allen, Jeff Berglund insists on the fact that 'humor is the best and sharpest weapon [American Indians] have always had against the ravages of conquest and assimilation.' (Berglund 2016, 10) Contrary to the stereotype according to which Indians are solemn and stoic, Native American people actually love to laugh. It is a spiritual tradition which releases stress and fosters connectiveness, as well as a political healing force, created in order to survive the countless attempts of cultural genocide, while showing a form of control of one's narratives (Tlanusta Garrett and Torres-Riviera 2005). Besides, Indian humor has historically worked as an 'ethnic glue' which mirrors 'red-white' intercultural exchanges, the use of jokes being a powerful instrument to decenter the certainties of 'structures' (Lincoln 1993). 
A group of Native American comedians, called the 1491s, understood the usefulness and the strength of such tools to disrupt the discourse built about indigenous people in the United States, and started to post videos that play with the visuality of the stereotypes associated with Native people, in a humorous way. The three members of the group, Sisseton Lakota Bobby Wilson, Osage Ryan Red Corn and Dine Dallas Goldtooth are based in Minnesota and shot their first video in 2009 (www.1491s.com).

They describe their creative productions as being 'indigenous satire' (www.1491s.com). Their aim is to challenge indigenous people to resist becoming complicit in the processes of simulation, through an assertion of 'visual sovereignty' (Berglund 2016). Several of their sketches, they come back on typical stereotypes about Native American people, and play with them to re-appropriate them, and take control of their image. In The Indian Store (https://www.youtube.com/watch?v=NuzPoidV4nI), they revisit the myths of the 'noble savage' and of the 'impossible modernity', by showing two Native young people 'red-facing' in an Indian gift shop in order to satisfy the tourists. For example, while they enter the shop in the morning wearing very common contemporary American clothes and talking American slang, as soon as the store opens, part of their selling role becomes being half naked and mumbling unintelligible words. In another sketch entitled New Moon Wolf Pack Audition (https://www.youtube.com/watch?v= BmFxJYFSXy0), which is a reminder of the second movie of the Twilight series, they mock cultural expectations of what a Native person should look and act, even in a contemporary setting, putting the emphasis on how people's image of Natives is still linked to the past and to the projections of clichés spread by Hollywood movies (www.1491s.com).

In those skits, comedy is used to draw attention to the ironic situation of Native American 'red-facing' or fabricating false and stereotyped identities to appeal to non-Native consumers. Its purpose is to enact criticism, and to 'push back against an ongoing post and new-colonialism'. Youtube is used because it enables a direct engagement, in a direct way with the public, the latter being able to leave comments and to give their opinion (Berglund 2016).

Pushing the idea of self-making through video making and posting, the 1491s are also at the origin of a project which puts cameras in between people's hands so that they can tell their stories and share them with other people throughout the country via Internet. They claim having created the project for two main reasons: to go against the 'Hollywood Indian', but also to fight the 'victimized Indian' image. They hence try to get away from the eternal image of 'ward', of being a 'dependent' people, a 'vanishing' one, asking especially the non-Native audience concerned by the latter statement to 'go cry over somebody else's tragedy. Because [Native people] are alive and thriving' (TedTalk 2013).

\section{Some limits to the new visual sovereignty: recognition, assimilation, and identity}

Although the different media that we saw previously, whether they are 'traditional', like cinematic productions, or 'digital', like user-generated platforms or social media, do represent the will and the ability of indigenous people to re-appropriate a technology which has first put them at a disadvantage, there still are some challenges, both theoretical and practical, that Native people have to face while using media technology. Indeed, even if the creations and interventions underlined earlier seem helpful to gain visual sovereignty, which itself can be used as a powerful tool for self-making and the assertion of self-determination and sovereignty, they still have to be circulated within a 
system which relies on a Western ideology, as mentioned in the introduction. First and foremost, there is a risk that visibility would not challenge the system but would only make it, in the Gramscian terminology, 'adapt' (Davila 2018a, b, c).

Then, media technology, as a produce of Western society, is still ubiquitous. If it came to be utilize by the majority of indigenous people, the challenge could lie in not crossing the line between adaptation and assimilation, while adopting unconsciously, not only the tools, but also the set of principles going with it (Shohat and Stam 2014). However, the criticism linked to the 'assimilation issue' could itself originate from a stereotype, the one linked to the impossibility for Natives to be 'modern', and hence the feeling of anomaly to see indigenous communities re-appropriating their image on the media (Deloria 2004). We could then interpret it as Native people using tools considered as modern by Westerners at the service of their own conception of modernity. Why would media not be assimilated in their system of thoughts? In this case, the question would not be on modernity, but on 'which modernity' (Davila 2018a, b, c).

One of the other pitfalls which needs to be avoided is the building of a 'politics of recognition' through media visibility. Even though the use of the media is also a way to raise awareness among a non-Native public, self-making should not be 'fixed by the look of another' and should constantly negotiate the difficulties entangled with the paradox of trying to convince the very structures oppressing indigenous people of their authenticity and of the legitimacy of their claims (Coulthard 2008). Indeed, self-representation and self-making are linked to building one's identity on his or her own terms. But 'does one actually decide one's own identity or is it applied from the outside, determined, socially constructed and performed?' (Smith 2011).

\section{The practical challenges of film distribution, internet access and media censorship}

In addition to the theoretical matters, practical obstacles are still to overcome to gain a complete visual sovereignty. As far as filmmaking is concerned, problems can arise in relation with the funding of the production, and then the diffusion. Indigenous filmmakers navigate between their desire to culturally express themselves and their will to win the support of major commercial industries. Therefore, they paradoxically rely on Hollywood funding, or to rely on private funds, convincing individuals to invest in an indigenous production (MacLean 2018). What is more, there is a difficulty of diffusion as well. Indigenous groups have been producing their own media for a while, but media owners, who are still predominantly part of the dominant fringe of the American population, mostly advantage the perspectives, values, and institutional structures of the Western settler society (Wilson and Stuart 2008). Consequently, feature-films and short films are never completely indigenous because directors have to deal with distribution (MacLean 2018).

Those issues can be put in conversation with the downside of succeeding in broadcasting indigenous production, the question of 'recognition'. However, this mere problem can actually raise awareness among white protagonists as well, as the creation of the Sundance Festival shows it. Indeed, in the sixties, American actor Robert Redford, though famous for playing in Western movies, wanted at a point to produce an independent movie about indigenous people. He realized how hard it was, because of the lack of space for such productions within the mainstream stage. His will afterwards was 
to create an independent film festival which would make room for indigenous creations, and he gave birth to the Sundance Festival, which is now of a major help for making Native American filmmakers more visible (MacLean 2018). Diane Fraher and her New York based artistic center Amerinda, came across the same type of trouble. Although the organization needed more space in the building to allow more artists to perform, the board deciding of the allocation of space, composed of white men, denied them the access, in order to give it to a white organization, underlining what is at stake as far as media production is concerned (Fraher 2017).

Concerning the new, digital media film, participants to the 2014 Indigenous Media Symposium underlined the fact that Native Americans had to find a way to 'produce their own contents, and then to distribute it on their own platforms, in order to create a common place in which they could protect their secret knowledge and help their language flourish'. Indeed, one of the panelists reminded the audience that although Twitter and Facebook could be useful, they also had the power to exert censorship (Panel Discussion, 'Indigenous New Media Symposium' 2014). As highlighted by this remark, there is hence a risk that off-line power structures would be reproduced on-line, as companies controlling social media are often repressing activists, silencing them under the pretext of the broadcasting of 'unwanted contents' (Cammaerts 2015).

Additionally, what has to be taken into account is that there still is a 'digital divide' in Indian Country, that is to say a very unequal access to internet and on-line media technology. How is it then possible to include the people who do not have an internet access for example? How could people who elaborate the claims reach out to this specific part of the indigenous population? To finish, some particularities of social media especially, seem to be in contradictions with some of the core values shared by an important number of indigenous communities, like taking time to speak face-to-face with somebody. As New York Apache social worker Noel Altaha highlighted, 'social media can be useful, but they do not replace the emotion and tone that a conversation in-person can convey' (Altaha 2018).

\section{Results and discussion: a critical analysis of the use of indigenous media}

The media that this article analysis put at the foreground are part of the 'white culture' Vine Deloria was talking about in the sixties, whether it is the cinema or digital media. Therefore, it is important to consider the pitfalls that can be linked with their utilization to foster indigenous self-representation, self-determination and sovereignty. Artists, scholars and activists are likely to face theoretical challenges, like the risk to fall into a 'politics of recognition', but also practical ones, from the difficulty for filmmakers to access both funding and the broadcasting industry, to the unequal internet coverage and the issues of the structural reproduction of power through computer-based technologies for digital media users.

However, the concrete examples introduced earlier exposed a successful and informed re-appropriation of both traditional and new media, in the purpose to foster cultural and political resistance, resurgence and sovereignty, through reclaiming visual representations and narratives, turning the Western media into Indigenous ones. Furthermore, the studied instances also demonstrated that indigenous media, and especially social media, had a significant impact on the 'invisibility' issue that a lot of Native Americans, as well as their demands, have to face on a daily basis. The question that 
we can then ask is if those increasingly used indigenous media would possibly lead to a global indigenous connection, creating a global community which could support local demands. These questions are important not only for making indigenous connections via media, but for challenging dominant view points in the broad field of education. Unless students are aware of the ways in which media and history interpretation and images shape the mass consciousness, there will be no progressive or enlightening education, locally and globally.

\section{Conclusion}

'Frantz Fanon's key point was that the anticolonial struggle would succeed only if it did more than just expel the colonizer; it had to do so in a way that decolonized the imaginations of the colonized subjects themselves. This could not happen if the colonized set their sights on reclaiming a collective cultural identity long since imposed on and corrupted by colonization. Rather, Fanon thought what was needed was the generation of a collective identity with 'values and shapes' appropriate for thriving in a decolonized context, and this identity could be shaped only in the struggle of the colonized to achieve liberation. In considering this idea in relation to Dakota scholar Philip Deloria's views, we can see that this direct anticolonial nationalist framework applied 'almost the same, but not quite' to the challenges facing indigenous people's politics in the contemporary American context. Deloria saw the need to decolonize the indigenous imagination because, as a result of American colonial imposition, 'Indians have come to believe that their problems were soluble by conformity to the white culture'. However, he did not encourage dualisms (Bruyneel 2004).

Consequently, the use of traditionally 'Western' media turned into indigenous media and used as tools of resistance and resurgence, is relevant within the framework of indigenous Nations' struggles for self-representation, self-determination and sovereignty. Nevertheless, the article has provided a critical discussion of the history, the challenges, the possibilities and the nature of Native American film and new media activism. Computer-based technology, and internet in particular, have been seen from the beginning as existing beyond the parameters of the body. But actually, it is possible to notice that internet is an important space to observe the production and above all the reproduction of culture, where whiteness is still assumed as being the 'norm', an issue supported by the observations of new media theorists (McPherson 2013).

Ultimately, the question of whose voice can be heard, and whose image is represented across indigenous Nations and within indigenous communities could also be raised. What is the main advantage of participatory media can also become an inconvenient, as it does not secure an official and unified account. Besides, it is challenging to reach an audience beyond the one who is already active politically speaking (Wilson and Stuart 2008).

\section{Abbreviations}

AIM: American Indian Movement; NAPT: Native American Public Telecommunications

\section{Acknowledgements}

I would like to thank Professor Natasa Lackovic for her expert feedback on my work, as well as for the precious advice she gave me when I was writing the article. I would also like to thank Professor Elizabeth Ellis for the knowledge on Native American history she passed on to me as one of her students, and for the passion and the skills with which she did so. 


\section{Competing interests}

The author declares that she has no competing interests.

\section{Publisher's Note}

Springer Nature remains neutral with regard to jurisdictional claims in published maps and institutional affiliations.

Received: 3 May 2018 Accepted: 26 July 2018

Published online: 22 August 2018

\section{References}

'1491s Play With Themselves, Imaginary and Reclamation' (2013) TedX Manitoba. www.youtube.com. Consulted March $21^{\text {st }}, 2018$ Adams P, Cupples J, Glynn K et al., (2017) Communications, Media, Geographies, Routledge, New York

Berglund J (2016) I'm Just an Indian Standing Before You with No Feathers Popping Out of My Head. Alternative 2(5):541

Boyd J (2015) An examination of native Americans in film and rise of native filmmakers. J Undergrad Res Commun 6(1): $105-114$

Bruyneel K (2004) The third space of sovereignty. In: The Postcolonial Politics of US-Indigenous Relations. University of Minnesota Press, Minneapolis

Cammaerts B (2015) Social media and activism. In: Marsell R (ed) The International Encyclopaedia of Digital Communication and Society. Wiley-Blackwell, Oxford

Clark E (2012) Social movement and social media, a qualitative study of occupy wall stree. Sodertorn University Research Report, Flemingsberg, pp 1-67

Cobb D (2002) Us Indians understand the basics, Oklahoma Indians and the politics of community action (1964-1970). Western Historical Quarterly 33(1):41-66

Conversation with Andrew MacLean, 2018

Conversation with Diane Fraher, 2017

Conversation with Elizabeth Ellis, 2018

Conversation with Noel Altaha, 2018

Coulthard G (2008) Red Skins, White Masks. University of Minnesota Press, Minneapolis

Cox, A (2017) 'Settler Colonialism', Oxford Bibliographies [on line]. www.oxfordbibliographies.com. Consulté le 1er mai 2018

Davila A (2018a) Design and the racing of space. In: NYU Graduate on Course Race and Visual Culture Spring 2018

Davila A (2018b) Racial ideologies and the media. In: Graduate Courses on Visual Culture and Media Spring 2018

Davila A (2018c) Visuality, modernity and race 1. In: Graduate Course on Race and Visual Culture Spring 2018

Deloria P (1998) Playing Indian. Yale University Press, New Haven

Deloria P (2004) Indians in unexpected places. University Press of Kansas, Lawrence

Ellis E, 'Beyond Standing Rock', Intervention. Retrieved from www.youtube.com. Accessed 20 Apr 2018a

Ellis E (2018b) Rejections Part 1. In: Graduate Course on Native American Histories Spring 2018

Fish A (2011) Indigenous digital media and the history of the internet on the Columbia plateau. J Northwest Anthropology 45:89-112

Frau-Meigs (2011) Media matters in the cultural contradictions of the 'information society'. Council of Europe Publishing, Strasbourg

Hall S (1995) The whites of their eyes, racist ideologies and the media. In: Dines G, Humez JM (eds) Gender, race and class in media. Sage Publications, California

Hearne J (2012) Native recognition: indigenous cinema and the western. State University of New York Press, Albany

Hearne J (2017) Native to the device, thoughts on digital indigenous studies. Studies in American Indian Literatures 29(1):3-26

Heppler J (2009) Framing red power: the American Indian movement, the trail of broken treaties and the politics of media, Dissertation. University of Nebraska, Lincoln, pp 1-94

Herrington L (2011) Fourth world film: politics of indigenous representation in mainstream and indigenous cinema, Undergraduate Honor Thesis. University of Colorado, Denver, pp 1-68

'Introduction to Media Theory', John Hopkins Center for Communication Programs, Session 13, Part. 1. 2018

Keene A (2016) 'Cultural appropriation or cultural appreciation? Exploring the fine line', Intervention at the University of Santa Cruz. Retrieved from www.youtube.com. Accessed 19 Mar 2018

Lee S, Summerfield E (2006) Native American culture: smoke signals. In: Lee S, Summerfield E (eds) Seeing the big picture: a cinematic approach to understanding culture in America. University of Michigan Press, Ann Arbor, pp 1-26

Lincoln K (1993) Indi'n humor: bicultural play in native America. Oxford University Press, New York

Littlejohn S, Foss K (2009) Encyclopedia of communication theory. Sage Publications, California

Loew P, Mella K (2005) Black ink and the new red power: native American newspapers and tribal sovereignty. In: Association for Education in Journalism and Mass Communication, pp 101-112

Manovich L (2001) The language of new media. MIT Press, Cambridge

Marrubio E, Buffalohead E (2013) Native Americans on film. University Press of Kentucky, Lexington

Mayo J (2013) Native American cinema: indigenous vision, Domestic Space and Historical Trauma. In: Thesis. School of Film and College of Fine Arts, Athens, pp 1-144

Mclaurin VA (2014) 'Stereotypes of Contemporary Native American Characters in Recent Popular Media', Master Thesis at the University of Massachusetts Amherst

McPherson T (2013) Keynote address. In: $8^{\text {th }}$ Encuentro at the Hemispheric Institute (Sao Paulo)

Murphee V (2016) Historical media analysis: oppression and resistance. In: Campbell C (ed) The Routledge companion to media and race. Taylor and Francis Group, Oxford

O'Brien J (2010) Firsting and lasting: writing Indians out of existence in New England. University of Minnesota Press, Minneapolis Panel Discussion, 'Indigenous New Media Symposium' (2014) The New School. Retrieved from www.thenewschool.edu. Accessed 18 Mar 2018 
Quijano A (2000) Coloniality of power, eurocentrism and Latin America. Nepantla 1(3):533-580

Raheja M (2010) Reservation Reelism. University of Nebraska Press, Lincoln

Reinschmidt K and al (2016) 'Shaping a story of resilience model from urban American Indian elders' Narratives of Historical Trauma and Resilience', Thesis, pp 63-87

Risling Baldy C (2016) The new native intellectualism. In: Wicazo Sa Review, pp 90-112

Rohr-Lopez A (2014) The impact of social media on social movements: the new opportunity and mobilizing structure. In: Thesis. Creighton University, Omaha, pp 1-22

Sawyer R (2011) 'The impact of new social media on intercultural adaptation', Senior Honors Project, 242, pp. 1-30

Simpson L (2016) 'Indigenous Resurgence and Co-Resistance', Critical Ethnic Studies 2:(2)

Shohat E, Stam R (2014) Unthinking eurocentrism: multiculturalism and the media. Routledge, New York

Smith C (2011) Enacting others. Duke University Press, Durham

Tlanusta Garrett M, Torres-Riviera E (2005) Laughing it up: native American humor as spiritual tradition. J Multicult Couns Devel 33:194-206

Trouillot J-R (2015) Silencing the past, power and the production of history. Beacon Press, Boston

Walker T (2014) Going Social. In: Native Peoples, pp 48-49

Walker W (2011) We Don't Live like this Anymore. American Indian Quarterly 35(4):479-516

Wilson P and al (2017) 'Indigenous Media', Oxford Bibliographies [on line]. Accessed 18 Dec 2017

Wilson P, Stuart M (2008) Global Indigenous Media: Culture. In: Poetics and Politics. Duke University Press, Durham Winton J (2014) 'All can participate in making change: revolutionizing indigenous media', Cultural Survival [on line]. Accessed 18 Dec 2018

Submit your manuscript to a SpringerOpen ${ }^{\odot}$ journal and benefit from:

- Convenient online submission

- Rigorous peer review

- Open access: articles freely available online

- High visibility within the field

- Retaining the copyright to your article

Submit your next manuscript at $\boldsymbol{\nabla}$ springeropen.com 